Psychiatry. 2000;68(2):207-10.

3. Carson AJ, Best S, Postma K, Stone J, Warlow C, Sharpe M. The outcome of neurology outpatients with medically unexplained symptons: a prospective cohort study. J Neurol Neurosurg Psychiatry. 2003; 74(7): 897-900.

4. Amorim P. Mini International Neuropsychiatric Interview (MINI): validação de entrevista breve para diagnóstico de transtornos mentais. Rev Bras Psiquiatr. 2000;22(3): 106-15.

5. Aaron LA, Buchwald D. A review of the evidence for overlap among unexplained clinical conditions. Ann Intern Med. 2001;134(9 Pt 2):86881. Review.

\section{Lack of association between a polymorphism of the norepinephrine transporter gene and schizophrenia in a Brazilian sample}

Dear Editor,

Post-mortem studies found increased levels of norepinephrine in the nucleus accumbens of patients with paranoid schizophrenia (SCZ). In chronic schizophrenic patients, the level of norepinephrine in the cerebrospinal fluid was increased. Medication-free relapsing patients also showed higher levels of norepinephrine and its metabolites in the cerebrospinal fluid. ${ }^{1}$ The norepinephrine turnover was increased during acute psychotic episodes. ${ }^{2}$ Early relapse of psychotic symptoms in patients with SCZ after neuroleptic (haloperidol) withdrawal was predicted by an increased noradrenergic activity during the treatment. ${ }^{3}$

Since SCZ has a genetic compound on its etiology ${ }^{4}$ and the noradrenergic system may be involved in the pathophysiology of the disorder, the norepinephrine transporter (NET) gene is a candidate for genetic studies on this disorder. NET is a $617-$ amino acid protein and its gene is located on chromosome 16 (16q12), consisting of 14 exons (protein coding regions). We performed a study using a silent mutation, $1287 \mathrm{~A} / \mathrm{G}$, located in the exon 9 to verify its association with SCZ. This variant is unlikely to have any functional effect. We compared the allelic and genotypic distributions between 211 DSM-IV schizophrenic patients and 283 healthy controls.
Genomic DNA was extracted from venous blood samples and the exonic silent polymorphism (1287 A/G) was analyzed in the Lab as described by Leszczynska-Rodziewicz et al. ${ }^{5}$ The $X^{2}$ test was applied to verify differences in allelic and genotypic distributions between patients with SCZ and controls. A two-tailed type I error rate of $5 \%$ was chosen for the statistical analysis.

The genotypic distributions were in Hardy-Weinberg equilibrium (SCZ: $p=0.41$; controls: $p=0.77$ ). We did not find differences in the allelic or genotypic distribution (Table 1 ). Our results, which are in concordance with Stöber et $\mathrm{al}^{6}$ and LeszczynskaRodziewicz et al, ${ }^{5}$ studies, do not support the association between the $1287 \mathrm{~A} / \mathrm{G}$ polymorphism in the NET gene with SCZ in our Brazilian sample.

\section{Quirino Cordeiro \\ Post-graduate student at the Department of Psychiatry of the Medical School of the University of São Paulo \\ Homero Vallada \\ Department of Psychiatry of the Medical School of the University of São Paulo}

\section{References}

1. Friedman JI, Adler DN, Davis KL. The role of norepinephrine in the pathophysiology of cognitive disorders: potential applications to the treatment of cognitive dysfunction in schizophrenia and Alzheimer's disease. Biol Psychiatry. 1999;46(9): 1243-52. Review.

2. Linnoila M, Ninan PT, Scheinin M, Waters RN, Chang WH, Bartko J, van Kammen DP. Reliability of norepinephrine and major monoamine metabolite measurements in CSF of schizophrenic patients. Arch Gen Psychiatry. 1983;40(12):1290-4.

3. van Kammen DP, Agren H, Yao JK, O'Connor DT, Gurklis J, Peters JL. Noradrenergic activity and prediction of psychotic relapse following haloperidol withdrawal in schizophrenia. Am J Psychiatry. 1994;151(3):379-84

4. Vallada Filho HP, Samaia H. Esquizofrenia: aspectos genéticos e estudos de fatores de risco. Rev Bras Psiquiatr. 2000;22(Supl I):SI2-SI4.

5. Leszczynska-Rodziewicz A, Czerski PM, Kapelski P, Godlewski S, Dmitrzak-Weglarz M, Rybakowski J, Hauser J. A polymorphism of the norepinephrine transporter gene in bipolar disorder and schizophrenia: lack of association. Neuropsychobiology. 2002;45(4):182-5.

6. Stöber G, Nöthen MM, Pörzgen P, Brüss M, Bönisch H, Knapp M, et al. Systematic search for variation in the human norepinephrine transporter gene: identification of five naturally occurring missense mutations and study of association with major psychiatric disorders. Am J Med Genet. 1996;67(6):523-32.

Table 1 - Allelic and genotypic distributions

\begin{tabular}{|c|c|c|c|c|}
\hline Alleles & & & 0.22 & 0.63 \\
\hline G & $104(24.64)$ & $147(25.97)$ & & \\
\hline Total & 422 (100) & $566(100)$ & & \\
\hline AA & $122(57.82)$ & $156(55.12)$ & & \\
\hline$A G$ & 74 (35.07) & $107(37.81)$ & & \\
\hline GG & $15(7.10)$ & $20(7.06)$ & & \\
\hline Total & $211(100)$ & $283(100)$ & & \\
\hline
\end{tabular}


This article has received corrections in agreement with the ERRATUM published in Volume 27 Number 1. 